\title{
Wine-making with Protection of Must against Oxidation in a Warm, Semi-arid Terroir
}

\author{
O. Corona
}

Dipartimento di Ingegneria e Tecnologie Agro-Forestali, Università degli Studi di Palermo, 90128 Palermo, Italy

Submitted for publication: November 2009

Accepted for publication: March 2010

Key words: Enzymatic oxidation, protection against oxidation

\begin{abstract}
To protect varietal aromas from oxidation before alcoholic fermentation, two grape must samples were prepared from white grapes potentially low in copper, pre-cooled and supplemented with ascorbic acid and solid $\mathrm{CO}_{2}$ (trial $\mathrm{A}_{\mathrm{CO} 2}$ ) or $\mathrm{SO}_{2}$ (trial $\mathrm{B}_{\mathrm{SO} 2}$ ). The wines prepared from musts protected from oxidation had aroma descriptors that included "passion fruit" and "grapefruit skin". The lower concentrations of flavanols in the $\mathrm{A}_{\mathrm{CO} 2}$ trial demonstrated that the use of solid $\mathrm{CO}_{2}$ as an oxidation preventative instead of $\mathrm{SO}_{2}$ reduced the extraction of these polyphenols from the grape solids. The higher concentration of hydroxycinnamoyl tartaric acids of the wine from the $\mathrm{A}_{\mathrm{CO} 2}$ trial with respect to $\mathrm{B}_{\mathrm{SO} 2}$ was ascribed to the lower grape polyphenoloxidase activity induced by the lower oxygen level in the $\mathrm{A}_{\mathrm{CO} 2}$ trial, or to the combination of caftaric acid quinone with the $\mathrm{SO}_{2}$ in $\mathrm{B}_{\mathrm{SO} 2}$. Although the grapes were very ripe (alcohol in wines $\sim \mathbf{1 4 . 5 \%} \mathrm{vol}$ ), the wines made with musts prepared by the two techniques were characterised by aroma descriptors like "passion fruit" and "grapefruit skin", and these aromas were not detected in the wines prepared from unprotected musts.
\end{abstract}

For the production of white wine, the grapes are usually pressed after destemming and crushing, and the must that is obtained after settling is fermented by yeasts at a temperature that generally is lower than $20^{\circ} \mathrm{C}$ (Bely et al., 1990). Enzymatic oxidation reactions may begin during harvest and the transport of grapes from the vineyard to the cellar, and are active at crushing (Iglesias et al., 1991; Macheix et al., 1991; Rigaud et al., 1991; Spanos \& Wrolstad, 1992). C6 saturated and unsaturated volatile aldehydes and alcohols are the products of the oxidation of unsaturated fatty acids catalysed by grape lipoxygenase (Cayrel et al., 1983; Zamora et al., 1985), and must browning is the result of polyphenol oxidation by grape polyphenol oxidase (PPO) (Wissemann \& Lee, 1980; Singleton et al., 1985; Singleton, 1987; Cheynier \& Ricardo da Silva, 1991). As polyphenols (mainly those of the class of flavanols) are also involved in wine browning (Tulyathan et al., 1989; Fernandez-Zorbano et al., 1995; Fernandez-Zorbano et al., 1998), their extraction from grape skin and seeds during must preparation should be minimised. In the presence of oxygen, PPO oxidises hydroxycinnamoyl tartaric acids, with the production of caftaric acid quinone that can be reduced by glutathione (if present), and the production of 2-S-glutathionyl caftaric acid (GRP, a colourless form) (Singleton et al., 1987). Caftaric acid quinone can also oxidise the other must phenolics as well as the same GRP (Cheynier \& Van Hulst, 1988), with the production of caftaric acid and quinones (coupled oxidation-reduction reactions) that give rise to the brown pigments responsible for must browning. In some cases, to reduce the phenolic content when the must is particularly rich in these compounds, PPO action is promoted throughout the contact of must with oxygen or air (must oxidation or hyper-oxidation) (Dubourdieu \& Lavigne, 1990; Cheynier et al., 1993; Schneider, 1998). Unfortunately, if this technique is used, odorous thiols, a class of aromas that is present in some grapes as cisteinyl derivatives (Darriet, 1993; Darriet et al., 1993;
Darriet et al., 1995; Bouchilloux et al., 1998; Tominaga et al., 1998; Peyrot des Gachons et al., 2000; Murat et al., 2001), can be oxidised, with a loss of the varietal characters of the wine. The free thiols released by yeasts from the above precursors during fermentation (Dubourdieu et al., 2006) can also be precipitated by copper from anti-mildew treatments in the vineyard (Darriet $e t$ al., 2001). Therefore, if the wines are to express odorous thiols, the must should be protected against oxidation (Rigaud et al., 1990; Rigaud et al., 2006), and vineyard treatments with coppercontaining pesticides should be limited (Darriet et al., 2001).

In this study, grape pre-cooling and two techniques to protect must against contact with atmospheric oxygen were tested in order to minimise PPO activity and to obtain wines endowed with aroma descriptors ascribed to odorous thiols. The influence of these techniques on the extraction of flavanols from grape solids was also studied. An additional aim of the experiments was to verify the possibility of producing wine from grape varieties that differed from Alsatian varieties but that still had aroma descriptors ascribed to odorous thiols (Tominaga et al., 2003).

\section{MATERIALS AND METHODS}

\section{Grapes and winemaking techniques}

Vinification experiments were performed in 2006 with Grillo grapes from a vineyard in the Marsala terroir (western Sicily). Grillo, a white variety indigenous to western Sicily, was used in the past to produce Marsala wines, and is now used for quality white wine production. The vineyard was trained to an espalier system, with Guyot pruning, 12 to 15 buds/vine and a planting density of 4000 vines/ha, corresponding to $2.5 \times 1 \mathrm{~m}$ spacing. Anti-mildew treatments with copper-containing pesticides were discontinued in mid-June, about two weeks after flowering.

Grapes (2 $000 \mathrm{~kg}$ ) were picked on 2006-09-17, put into 10 to 12 $\mathrm{kg}$ plastic crates, moved to the winery and stored in a refrigerated 
room for about 30 hours at $8^{\circ} \mathrm{C}$ to avoid PPO activity at crushing and the extraction of polyphenol when passed through a heat exchanger.

Two experiments relating to the protection of must against oxidation by $\mathrm{CO}_{2}\left(\mathrm{~A}_{\mathrm{CO} 2}\right)$ and $\mathrm{SO}_{2}\left(\mathrm{~B}_{\mathrm{SO} 2}\right)$ were carried out, each on $1000 \mathrm{~kg}$ of refrigerated grapes.

The first was the $\mathrm{A}_{\mathrm{CO} 2}$ trial, during which previously refrigerated grapes were destemmed, crushed and stored in a $10 \mathrm{hL}$ vat in which previously solid $\mathrm{CO}_{2}(50 \mathrm{~g} / 100 \mathrm{~kg})$ had been placed. During crushing, $15 \mathrm{~g} / 100 \mathrm{~kg}$ ascorbic acid, $0.8 \mathrm{~mL} / 100 \mathrm{~kg}$ maceration enzymes (Endozym ICS 10 Arômes, Pascal Biotech), 0.8 mL/100 $\mathrm{kg}$ pectolytic enzymes (Endozym ICS 10 Èclairs, Pascal Biotech) and solid $\mathrm{CO}_{2}(50 \mathrm{~g} / 100 \mathrm{~kg})$ were added. After cold maceration at $10^{\circ} \mathrm{C}$ for 24 hours, the crushed grapes were pressed (Drain Press SF 18, Puleo s.r.l., Marsala, Sicily). Prior to the introduction of the crushed grapes a small amount of solid $\mathrm{CO}_{2}$ was added to the press, and the pressing was started after solid $\mathrm{CO}_{2}$ sublimation. After pressing (max 0.2 bar), free run must $(6.5 \mathrm{hL})$ was sent to a $10 \mathrm{hL}$ tank in which $50 \mathrm{~g} / 100 \mathrm{~kg}$ solid $\mathrm{CO}_{2}$ had been placed and clarified by static settling at $10^{\circ} \mathrm{C}$ for 20 hours. The clear must $(6$ $\mathrm{hL}$ ) was acidified with $160 \mathrm{~g} / \mathrm{hL}$ tartaric acid, charged with $10 \mathrm{~g} / \mathrm{hL}$ diammonium phosphate (DAP) containing thiamine $(0.25 \%)$, and fermented by inoculation of $20 \mathrm{~g} / \mathrm{hL}$ reactivated dry yeast (Sinergie Levuline C19/ALS, Groupe Oeno France). During fermentation (the temperature was $18^{\circ} \mathrm{C}$ ), when the amount of alcohol reached $3 \%$ and $8 \%$ vol respectively, 10 and $5 \mathrm{~g} / \mathrm{hL}$ of DAP were added and one-third of the must volume was pumped over in air.

The second trial was the $\mathrm{B}_{\mathrm{SO} 2}$ trial. In comparison to the $\mathrm{A}_{\mathrm{CO} 2}$ trial, $\mathrm{B}_{\mathrm{SO} 2}$ differed in the time of cold pre-fermentative maceration (three hours rather than the usual 24-hour period, to avoid excessive extraction of phenolics induced by the presence of $\left.\mathrm{SO}_{2}\right)$. Potassium meta-bisulphite $(10 \mathrm{~g} / 100 \mathrm{~kg})$ was added to the crushed grapes instead of solid $\mathrm{CO}_{2}$. Neither $\mathrm{SO}_{2}$ nor solid $\mathrm{CO}_{2}$ was added in subsequent operations prior to the alcoholic fermentation. During fermentation, the must was charged with 20 $\mathrm{g} / \mathrm{hL}$ of DAP containing thiamine $(0.25 \%)$.

The control wine was prepared according to the usual technique of the cellar. The grapes were picked manually, transported to the cellar in big crates, destemmed, crushed, and $10 \mathrm{~g} / 100 \mathrm{~kg}$ of potassium meta-bisulphite were added, as well as maceration and pectolytic enzymes. The juice was clarified using flotation by sparging with air. During fermentation (the temperature was $20^{\circ} \mathrm{C}$ ), the must was supplemented with $30 \mathrm{~g} / \mathrm{hL}$ of DAP containing thiamine $(0.25 \%)$.

At the end of alcoholic fermentation, $100 \mathrm{mg} / \mathrm{L} \mathrm{SO}_{2}$ (as potassium meta-bisulphite) was added to three wines, and they were stored sur lies in stainless steel tanks at about $16^{\circ} \mathrm{C}$ for one month, with bâtonnages once a week. In December, samples for chemical, physical and sensory analyses were taken and refrigerated at $5^{\circ} \mathrm{C}$.

\section{Chemicals, instrumentation and analysis}

Determinations of the concentrations of alcohol, extract, total acidity, $\mathrm{pH}$, volatile acidity and free and total $\mathrm{SO}_{2}$ were performed according to EEC 2676 standard procedure (EEC, 1990). Ash alkalinity was determined using the indirect method according to Usseglio-Tomasset and Garcia Moruno (1993), and buffer power $(\mathrm{dB} / \mathrm{dpH})$ in the ratio $10 / \Delta \mathrm{pH}$, where $\Delta \mathrm{pH}$ is the difference between the $\mathrm{pH}$ of the wine and that of the same wine to which $10 \mathrm{meq} / \mathrm{L}$ $\mathrm{NaOH}$ has been added (Usseglio-Tomasset, 1995). The reactivity of flavanols to p-dimethylamino-cinnamaldehyde (p-DAC assay) was determined by UV-Vis spectrophotometry (Delcour \& Janssens de Varebeke, 1985) (Beckman DU 640 spectrophotometer, Milan, Italy) as being (+)-catechin equivalent. Hydroxycinnamoyl tartaric acids (HCTA) was tested by HPLC (Di Stefano \& Cravero, 1992). The standard employed was chlorogenic acid, and the concentration of HCTA was expressed as chlorogenic acid equivalents. By processing these data (hypothetical identity of $\varepsilon$ for chlorogenic and caftaric acids at $220 \mathrm{~nm}$ and the data from the coefficients determined by injecting free hydroxycinnamic acids and chlorogenic acid), the concentration of caftaric, coutaric and fertaric acids was estimated. 2-S-glutathionyl caftaric acid was evaluated as caftaric acid equivalent. The analysis of fixed acids was performed by HPLC on an Agilent series 2100 instrument (Milan, Italy) equipped with a $\mathrm{C}_{18}$ column (Econosphere ${ }^{\mathrm{TM}} \mathrm{C}_{18}$, $5 \mu \mathrm{m}, 250 \times 4.6 \mathrm{~mm}$ i.d., Lokeren, Belgium, part $\mathrm{n}^{\circ} 70066$ ), volume injected $20 \mu \mathrm{L}$, flow rate $0.6 \mathrm{~mL} / \mathrm{min}$., detection at 210 $\mathrm{nm}$. Prior to injection, $0.5 \mathrm{~mL}$ of sample was stripped of phenolics by passing it through a $400 \mathrm{mg} \mathrm{C}_{18}$ Sep Pack cartridge (Sep Pak, Waters, Milan, Italy, part ${ }^{\circ}$ WAT036810), activated with $2 \mathrm{~mL}$ of methanol, followed by $3 \mathrm{~mL}$ of $\mathrm{H}_{3} \mathrm{PO}_{4} 10^{-3} \mathrm{M}$ and elution with $\mathrm{H}_{3} \mathrm{PO}_{4} 10^{-3} \mathrm{M}$ until a volume of $10 \mathrm{~mL}$ was reached. Free volatiles were determined according to the method outlined by Gianotti and Di Stefano (1991). In brief, $25 \mathrm{~mL}$ of wine, charged with 1-Heptanol as internal standard $(0.25 \mathrm{~mL}$ of $40 \mathrm{mg} / \mathrm{L}$ hydroalcoholic solution), diluted to $75 \mathrm{~mL}$ with distilled $\mathrm{H}_{2} \mathrm{O}$, were passed through a $1 \mathrm{~g} \mathrm{C}_{18}$ cartridge (Isolute, SPE Columns, Uppsala, Sweden, part $\mathrm{n}^{\circ} 221-0100-\mathrm{C}$ ) previously activated with $3 \mathrm{~mL}$ of methanol followed by $4 \mathrm{~mL}$ of distilled $\mathrm{H}_{2} \mathrm{O}$. After washing with $30 \mathrm{~mL}$ of distilled $\mathrm{H}_{2} \mathrm{O}$, volatiles were recovered by elution with $12 \mathrm{~mL}$ dichloromethane, dehydrated and evaporated to $0.5 \mathrm{~mL}$ prior to injection into the gas chromatograph (PerkinElmer Autosystem XL, Milan, Italy) and GC-MS (Agilent 6890 Series GC system, Agilent 5973 Net Work Mass Selective Detector, Milan, Italy), both equipped with a DB-WAX column (Agilent Technologies, $30 \mathrm{~m}, 0.250 \mathrm{~mm}$ i.d., film thickness 0.25 $\mu \mathrm{m}$, part $\left.\mathrm{n}^{\circ} 122-7032\right)$.

Oven temperatures: $40^{\circ} \mathrm{C}$ for 2 min (during splitless injection), from 40 to $60^{\circ} \mathrm{C}, 40^{\circ} \mathrm{C} / \mathrm{min}, 60^{\circ} \mathrm{C}$ for $2 \mathrm{~min}$, from 60 to $190^{\circ} \mathrm{C}$, $2^{\circ} \mathrm{C} / \mathrm{min}$, from 190 to $230,5^{\circ} \mathrm{C} / \mathrm{min}, 230^{\circ} \mathrm{C}$ for $15 \mathrm{~min}$; injector $250^{\circ} \mathrm{C}$, Fid $250^{\circ} \mathrm{C}$, transfer line $230^{\circ} \mathrm{C}$, carrier helium $1 \mathrm{~mL} / \mathrm{min}$.; EM. $70 \mathrm{eV}$. The identification of volatiles was done by injection of commercial standards or others prepared in our laboratory (ethyl esters of 2-hydroxyglutaric acid) (Di Stefano, 1983).

All the solvents and reagents were purchased from WWR International, Milan, Italy. The chemical and physical determinations were performed in triplicate.

\section{Sensory evaluation of wines}

In June 2007, after six months' storage in bottles at $5^{\circ} \mathrm{C}$, the wines were subjected to qualitative sensory analysis (duo-trio and preference tests) at Marsala (Sicily, Italy) by a trained panel of 27 judges consisting of oenologists and students following the Viticulture and Oenology course of the University of Palermo. The judges were also asked to evaluate whether the two wines were characterised by aromas attributable to the descriptors passion fruit and grapefruit skin, and which was more intense. Prior to the 
sensorial analysis the panel of judges was familiarised with these aromas by smelling fresh passion fruit and grapefruit skin.

\section{Statistical analysis}

To compare the mean values of any compound, the Student's t-test was performed with the SPSS software package (version 13).

\section{RESULTS AND DISCUSSION}

\section{Wine composition}

The composition of the $\mathrm{A}_{\mathrm{CO} 2}$ and $\mathrm{B}_{\mathrm{SO} 2}$ wines (Table 1) was quite similar, although some differences were found in ash alkalinity ( $p$ $\leq 0.05$ ), total flavanols ( $\mathrm{p}$-DAC assay) and $\mathrm{SO}_{2}$. The differences in $\mathrm{SO}_{2}$ content were due to the fact that, in the $\mathrm{B}_{\mathrm{SO}_{2}}$ trial, $\mathrm{SO}_{2}$ was present prior to the addition of potassium meta-bisulphite at the end of alcoholic fermentation. On the other hand, the composition of the control wine was different from that of the $\mathrm{A}_{\mathrm{CO} 2}$ and $\mathrm{B}_{\mathrm{SO} 2}$. In this wine, malolactic fermentation occurred at the end of alcoholic fermentation, prior the addition of $\mathrm{SO}_{2}$ and storage. The high ethanol content (about $14.5 \%$ vol for the trials) means that the vinified grapes were very ripe and rich in sugars, as is normal in western Sicily.

The absence of $\mathrm{SO}_{2}$ in the must of the $\mathrm{A}_{\mathrm{CO} 2}$ trial allowed us to minimise the extraction of flavanols during the contact of the must with grape solids, as proven by the p-DAC assay, which gave a lower result in the $\mathrm{A}_{\mathrm{CO} 2}$ wine than in $\mathrm{B}_{\mathrm{SO} 2}$ (Table 1).

The difference between the two trials is even clearer when we note that, in $\mathrm{A}_{\mathrm{CO} 2}$, the must remained in contact with solid grape parts for a longer time than in $\mathrm{B}_{\mathrm{SO} 2}$. The smaller content of flavanols in the control can be due to the enzymatic oxidation reactions that occurred during must preparation. The fact that the
$\mathrm{A}_{\mathrm{CO} 2}$ wine contained far more hydroxycinnamoyl tartaric acids than $\mathrm{B}_{\mathrm{SO} 2}(\mathrm{p} \leq 0.001)$ (Figure 1$)$, apparently in contradiction to the above statement, could prove that the solid $\mathrm{CO}_{2}$ preserved it against must contact with oxygen. Nevertheless, the presence of GRP (Okuda \& Yokotsuka, 1999) could prove that the PPO was also active in the $\mathrm{A}_{\mathrm{CO} 2}$ wine, although to a lesser extent than in $\mathrm{B}_{\mathrm{SO} 2}$, and that the complete inactivation of these enzymes was not possible in the operative conditions of this work.

In accordance with findings of Makhotkina and Kilmartin (2009), the minor content of caftaric acid and GRP in the $\mathrm{B}_{\mathrm{SO} 2}$ wine could be due to the reaction of caftaric acid quinone with $\mathrm{SO}_{3} \mathrm{H}^{-}$, from which compounds similar in structure to the GRP are produced. The caftaric acid quinone that reacted with $\mathrm{SO}_{3} \mathrm{H}^{-}$was subtracted to the reaction with glutathione and flavanols. Such a model explains the lower content of caftaric acid in the $\mathrm{B}_{\mathrm{SO}_{2}}$ wine with respect to $\mathrm{A}_{\mathrm{CO} 2}$, and confirms that, during the preparation of the $\mathrm{B}_{\mathrm{SO} 2}$ trial must, a higher amount of caftaric acid quinone was produced as well as that the PPO was more active. The very small amounts of caftaric $(6 \mathrm{mg} / \mathrm{L})$ and coutaric acids $(1 \mathrm{mg} / \mathrm{L})$ in the control suggest that enzymatic hyper-oxidation reactions occurred.

\section{Volatile compounds in wines}

In both the $\mathrm{A}_{\mathrm{CO} 2}$ and $\mathrm{B}_{\mathrm{SO} 2}$ trials, the resulting wines were rich in ethyl esters of medium-chain fatty acids, with a slight difference in favour of $\mathrm{A}_{\mathrm{CO} 2}$ (Table 2).

The content of medium-chain fatty acids was not high in the $\mathrm{A}_{\mathrm{CO} 2}$ or $\mathrm{B}_{\mathrm{SO} 2}$ wines. In agreement with Houtman and Du Plessis, (1986) higher amounts of these compounds would be expected for wines obtained from clarified musts. Furthermore, the ratios

\section{TABLE 1}

Composition of $\mathrm{A}_{\mathrm{CO} 2}$ (trial with solid $\mathrm{CO}_{2}$ ), $\mathrm{B}_{\mathrm{SO} 2}$ (trial with $\mathrm{SO}_{2}$ ) and control wines

\begin{tabular}{|c|c|c|c|c|}
\hline & & Control & $\mathbf{A}_{\mathrm{CO} 2}$ & $\mathrm{~B}_{\mathrm{SO} 2}$ \\
\hline $\mathrm{pH}$ & & 3.4 & $3.1 \pm 0.3$ & $3.1 \pm 0.3$ \\
\hline Alcohol level & $\%, \mathrm{v} / \mathrm{v}$ & 14.2 & $14.4 \pm 0.0$ & $14.6 \pm 0.0$ \\
\hline Extract & $\mathrm{g} / \mathrm{L}$ & 20.1 & $22.6 \pm 0.5$ & $20.9 \pm 0.5$ \\
\hline Total acidity ${ }^{\dagger}$ & $\mathrm{meq} / \mathrm{L}$ & 87.7 & $81.1 \pm 1.6$ & $82.0 \pm 1.8$ \\
\hline Volatile acidity & $\mathrm{meq} / \mathrm{L}$ & 7.5 & $3.7 \pm 0.4$ & $3.7 \pm 0.4$ \\
\hline Tartaric acid & $\mathrm{g} / \mathrm{L}$ & 3.1 & $3.3 \pm 0.1$ & $3.5 \pm 0.1$ \\
\hline Malic acid & $\mathrm{g} / \mathrm{L}$ & $0.6^{\prime \prime}$ & $0.6 \pm 0.0$ & $0.6 \pm 0.0$ \\
\hline Buffer power & $\mathrm{meq} / \mathrm{L}$ & 37.4 & $33.3 \pm 0.9$ & $33.3 \pm 0.9$ \\
\hline Ash alkalinity & $\mathrm{meq} / \mathrm{L}$ & 21.0 & $15.6 \pm 0.4 *$ & $14.7 \pm 0.3$ \\
\hline Free $\mathrm{SO}_{2}$ & $\mathrm{mg} / \mathrm{L}$ & 15.0 & $18.0 \pm 0.7 * * *$ & $24.0 \pm 0.6$ \\
\hline Total $\mathrm{SO}_{2}$ & $\mathrm{mg} / \mathrm{L}$ & 98.0 & $86.0 \pm 0.9 * *$ & $107.0 \pm 0.9$ \\
\hline p-DAC assay ${ }^{\S}$ & $\mathrm{mg} / \mathrm{L}$ & 13.8 & $24.5 \pm 0.1 *$ & $28.6 \pm 0.1$ \\
\hline
\end{tabular}

\section{†as tartaric acid}

${ }^{\ddagger}$ as acetic acid

$\S$ as $(+)$-catechin

"lactic acid

All data represent mean value \pm standard deviation ( $\mathrm{n}=3$ for trials, $\mathrm{n}=1$ for control).

Significant differences between treatments are indicated by $* * *, * * *$ at $\mathrm{p} \leq 0.05,0.01,0.001$ respectively. Only trial data were submitted to the statistical analysis. 
TABLE 2

Fermentative, pre-fermentative and post-fermentative volatiles of $\mathrm{A}_{\mathrm{CO} 2}$ (trial with solid $\mathrm{CO}_{2}$ ), $\mathrm{B}_{\mathrm{SO} 2}$ (trial with $\mathrm{SO}_{2}$ ) and control wines $(\mu \mathrm{g} / \mathrm{L})$, determined by absorption of lypophilic volatiles of wine on $\mathrm{C}_{18}$ cartridge and elution with dichloromethane

\begin{tabular}{|c|c|c|c|}
\hline & Control & $\mathbf{A}_{\mathrm{CO} 2}$ & $\mathbf{B}_{\mathrm{SO} 2}$ \\
\hline Isoamyl acetate & 2147 & $2670 \pm 123 *$ & $3046 \pm 140$ \\
\hline Ethyl hexanoate & 579 & $1047 \pm 59$ & $1031 \pm 58$ \\
\hline Hexyl acetate & 959 & $183 \pm 8$ & $187 \pm 9$ \\
\hline 3-Methyl-pentan-1-ol & 18 & $73 \pm 9 *$ & $103 \pm 12$ \\
\hline 4-Methyl-pentan-1-ol & 57 & $155 \pm 18 *$ & $105 \pm 12$ \\
\hline 1-Hexanol & 671 & $976 \pm 45$ & $926 \pm 48$ \\
\hline Trans-3-hexenol & n.d. & $27 \pm 3 * * *$ & $83 \pm 9$ \\
\hline Cis-3-hexenol & 72 & $63 \pm 7$ & $80 \pm 9$ \\
\hline Ethyl octanoate & 959 & $1961 \pm 90$ & $1894 \pm 87$ \\
\hline Ethyl-2-OH-4-methyl-pentanoate & 56 & $56 \pm 5$ & $46 \pm 4$ \\
\hline Ethyl-2-furoate & n.d. & $55 \pm 6 * * *$ & n.d. \\
\hline Ethyl decanoate & 328 & $812 \pm 37 * *$ & $624 \pm 34$ \\
\hline Diethyl succinate & 1695 & $1058 \pm 57$ & $1073 \pm 61$ \\
\hline Ethyl-9-decenoate & 107 & $35 \pm 2 * * *$ & $51 \pm 2$ \\
\hline Phenetyl acetate & 342 & $365 \pm 17$ & $410 \pm 23$ \\
\hline Ethyl dodecanoate & n.d. & $122 \pm 6 * * *$ & $50 \pm 3$ \\
\hline Hexanoic acid & 5345 & $934 \pm 53 * * *$ & $500 \pm 23$ \\
\hline Phenetyl alcohol & 24506 & $15369 \pm 3197$ & $13850 \pm 2881$ \\
\hline Octanoic acid & 11586 & $1575 \pm 89 * * *$ & $926 \pm 43$ \\
\hline Diethyl-2-OH-glutarate & 66 & $271 \pm 27 * *$ & $166 \pm 18$ \\
\hline Monoethyl-2-OH-glutarate & 127 & $97 \pm 9 * *$ & $67 \pm 8$ \\
\hline Decanoic acid & 3539 & $274 \pm 13 * *$ & $218 \pm 12$ \\
\hline
\end{tabular}

n.d. $=$ not detected

All data represent mean value \pm standard deviation ( $\mathrm{n}=3$ for trials, $\mathrm{n}=1$ for control)

Significant differences between treatments are indicated by $*, * * * * *$ at $\mathrm{p} \leq 0.05,0.01,0.001$ respectively. Only trial data were submitted to the statistical analysis

between hexanoic and octanoic acids were different from those of the corresponding esters (Figure 2). The content of ethyl esters of medium-chain fatty acids and of medium-chain fatty acids of the control (respectively lesser and higher than the $\mathrm{A}_{\mathrm{CO} 2}$ and $\mathrm{B}_{\mathrm{SO} 2}$ trials), show that the vinification technique affected the production of fermentation volatiles. The differences between the $\mathrm{A}_{\mathrm{CO} 2}$ and $\mathrm{B}_{\mathrm{SO} 2}$ trials are significant at $\mathrm{p} \leq 0.01$ for medium-chain fatty acids and ethyl decanoate. Acetates of fermentative and pre-fermentative alcohols, particularly isoamyl acetate, reached maximum values in $\mathrm{B}_{\mathrm{SO} 2}(\mathrm{p} \leq 0.05$ for isoamyl acetate) (Figure 2 ). Acetates and ethyl esters were also particularly high, in spite of the hydrolytic reactions that certainly occurred during storage, as proven by the presence in both wines of nearly $1 \mathrm{mg} / \mathrm{L}$ of diethyl succinate, the content of which is proportional to the chemical age of the wine (intensity of hydrolytic and esterification reactions) (Marais \& Pool, 1980; Francioli et al., 2003; Di Stefano, personal communication). The trans-3-hexenol/cis-3-hexenol ratio was greater than 1 in $\mathrm{B}_{\mathrm{SO} 2}$ and lower than 1 in $\mathrm{A}_{\mathrm{CO} 2}$ (Table 2), probably due to the different techniques used for preparing the musts (Nicolini et al., 1996). Nevertheless, the differences between the two treatments were not significant.

\section{Sensory analysis}

The sensory analysis showed that even though enzymatic oxidation reactions occurred, grapefruit and passion fruit aromas were still evident in the wines. The control was not included in the duo-trio test because it lacked passion fruit and grapefruit skin aromas. In both the $\mathrm{A}_{\mathrm{CO} 2}$ and $\mathrm{B}_{\mathrm{SO} 2}$ wines, these aroma descriptors were so intense that they overwhelmed those of the fermentative esters.

The duo-trio test showed significant differences between the two trials, at the $1 \%$ level (Roessler et al., 1978). Most of the judges (20 out of 27) were able to detect differences between 


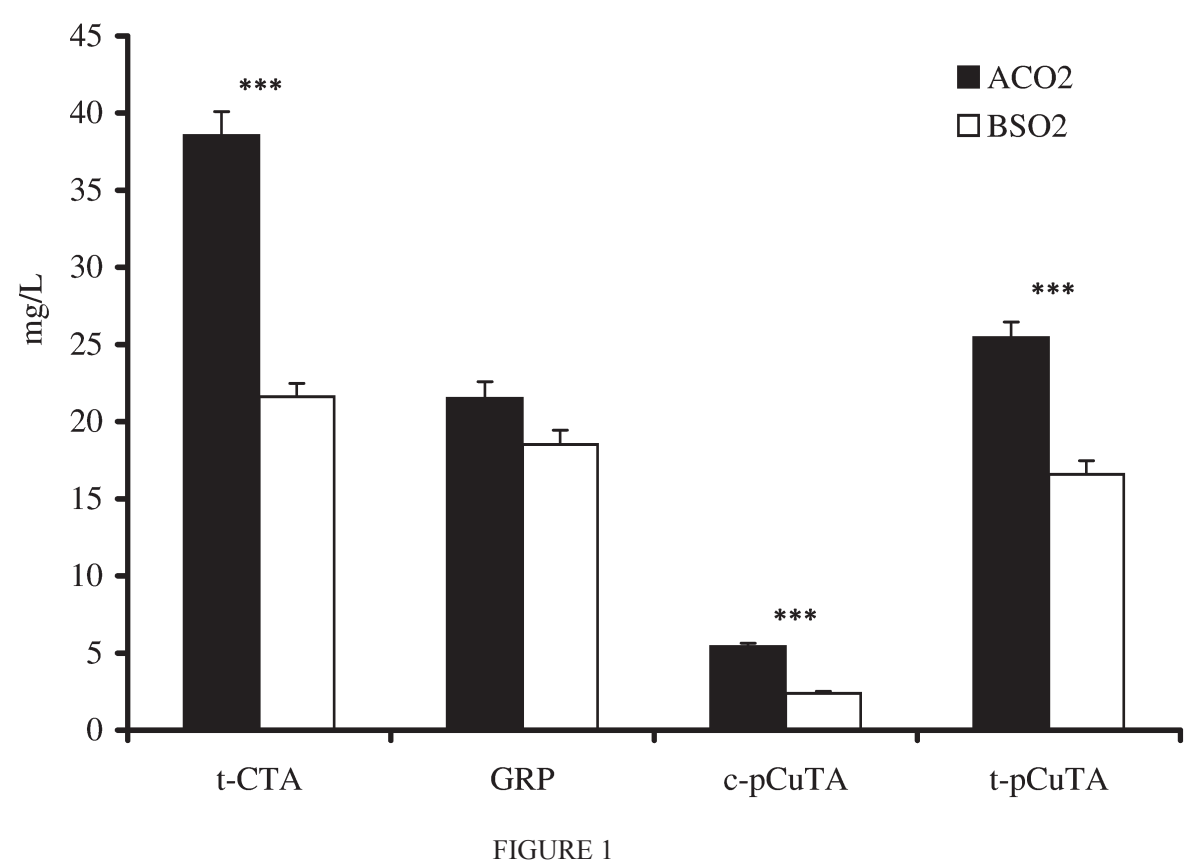

Hydroxycinnamoyl tartaric acids and GRP of $\mathrm{A}_{\mathrm{CO} 2}$ (trial with solid $\mathrm{CO}_{2}$ ) and $\mathrm{B}_{\mathrm{SO} 2}$ (trial with $\mathrm{SO}_{2}$ ) wines $(\mathrm{mg} / \mathrm{L}$ ) (t-CTA: trans-caffeoyl tartaric acid, c,t-pCuTA: cis,transp-coumaroyl tartaric acid, GRP: grape reaction product). Mean \pm standard deviation; $\mathrm{n}=3$. Significant differences between treatments are indicated by $* * *$ at $\mathrm{p} \leq 0.001$. Control was not included since the content of hydroxycinnamoyl tartaric acids was very small.

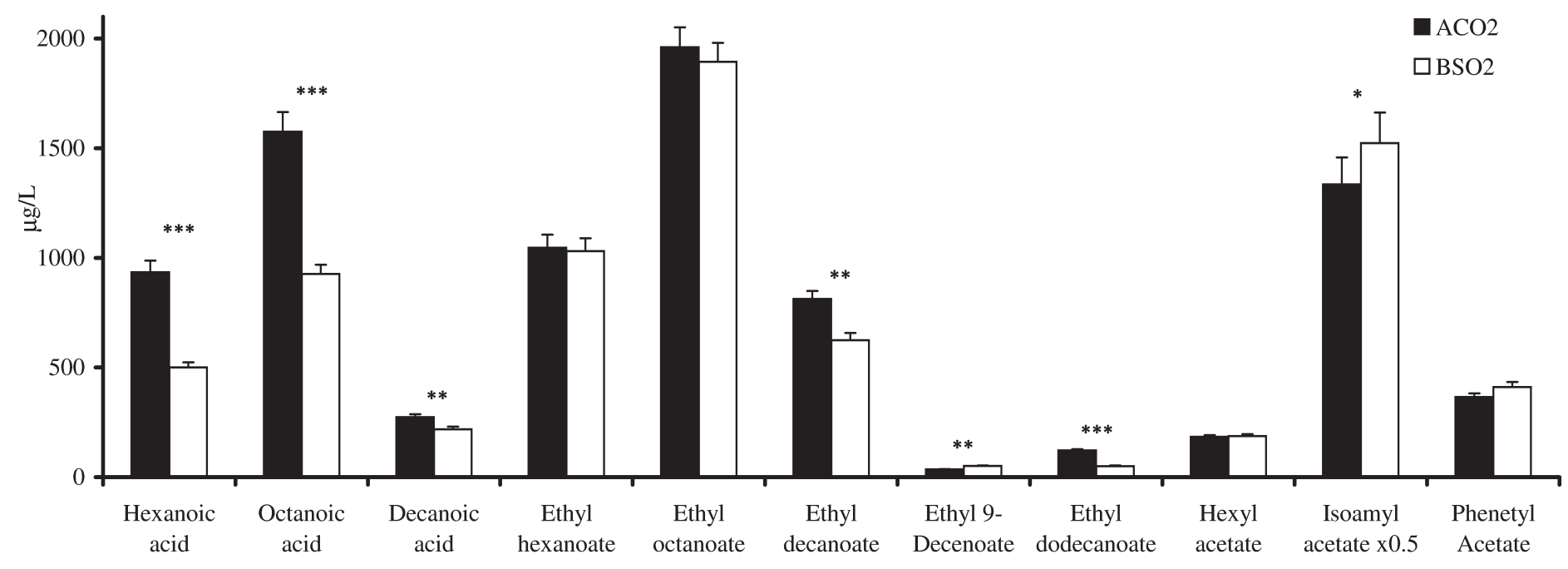

FIGURE 2

Medium-chain fatty acids, their ethyl esters and acetates of pre-fermentative and fermentative alcohols of $\mathrm{A}_{\mathrm{CO} 2}$ (trial with solid $\mathrm{CO}_{2}$ ) and $\mathrm{B}_{\mathrm{SO} 2}$ (trial with $\mathrm{SO}_{2}$ ) wines $\left(\mathrm{mg}_{\mathrm{O}} \mathrm{L}\right.$ ). Data has not been reported for the control. Mean \pm standard deviation; $\mathrm{n}=3$. Significant differences between treatments are indicated by *,**,*** at $\mathrm{p} \leq 0.05,0.01,0.001$ respectively.

the wines made with the two different techniques, although the preference test did not highlight any significant differences. Some of the 11 descriptors identified by the judges referred to passion fruit, aromatic grasses, grapefruit skin and fermentative esters, such as pineapple, banana and green apple.

\section{CONCLUSIONS}

The use of solid $\mathrm{CO}_{2}$ in place of sulphur dioxide allowed us to prolong cold maceration of the must with grape solids, with fewer flavanols extracted than in the case of $\mathrm{SO}_{2}$ treatment, in which case a shorter contact time was applied. Under these conditions, as deduced from the concentrations of hydroxycinnamoyl tartaric acids and the GRP of the wines, PPO activity was only partly inhibited. Nevertheless, grape refrigeration as well as both solid $\mathrm{CO}_{2}$ and $\mathrm{SO}_{2}$ were able to protect the varietal aromas from oxidation. Vinification of the control wine without protecting the must from oxidation seemed to destroy the varietal aromas. To our knowledge, this work shows for the first time that descriptors such as passion fruit and grapefruit skin can be applied even to wines from Mediterranean grape varieties.

\section{LITERATURE CITED}

Bely, M., Sablayrolles, J.M. \& Barre, P., 1990. Description of alcoholic fermentation kinetics: its variability and significance. Am. J. Enol. Vitic. 41(4), 319-324. 
Bouchilloux, P., Darriet, P., Henry, R., Lavigne-Cruège, V. \& Dubourdieu D., 1998. Identification of volatile and powerful odorous thiols in Bordeaux red wine varieties. J. Agric. Food Chem. 46(8), 3095-3099.

Cayrel, A., Crouzet, J., Chan, H.W.S. \& Price, K.R., 1983. Evidence for the occurrence of lipoxygenase activity in grapes (variety Carignane). Am. J. Enol. Vitic. 34, 77-82

Cheynier, V. \& Ricardo da Silva, J.M.R., 1991. Oxidation of grape procyanidins in model solutions containing trans-caffeoyltartaric acid and polyphenol oxidase. J. Agric. Food Chem. 39, 1047-1049.

Cheynier, V. \& Van Hulst, M.W.J., 1988. Oxidation of trans-caftaric acid and 2-Sglutathionylcaftaric acid in model solutions. J. Agric. Food Chem. 36, 10-15.

Cheynier, V., Masson, G., Rigaud, J. \& Moutounet, M., 1993. Estimation of must oxidation during pressing in Champagne. Am. J. Enol. Vitic. 44(4), 393-399.

Darriet, P., 1993. L'arome et les précurseurs d'arome du Sauvignon. Thesis, Universitè de Bordeaux II

Darriet, P., Bouchilloux, P., Poupot, C., Bugaret, Y., Clerjeau, M., Sauris, P., Medina, B. \& Dubourdieu, D., 2001. Effect of copper fungicide spraying on volatile thiols of the varietal aroma of Sauvignon blanc, Cabernet Sauvignon and Merlot wines. Vitis 40, 93-99.

Darriet, P., Tominaga, T., Demole, E. \& Dubourdieu, D., 1993. Mise en évidence dans le raisin de Vitis vinifera (var. Sauvignon) d'un précurseur de la 4-mercapto4-méthyl pentan-2-one. C.R. Acad Sci. Biol. Pathol. Végét. 316, 1332-1335.

Darriet, P., Tominaga, T., Lavigne, V., Boidron, J.N. \& Dubourdieu, D. 1995. Identification of a powerful aromatic component of Vitis vinifera L. var. Sauvignon wines: 4-mercapto-4-methylpentan-2-one. J. Flav. Frag. 10, 385-392.

Delcour, J.A. \& Janssens de Varebeke, D., 1985. A new colorimetric assay for flavonoids in pilsner beer. J. Inst. Brew. 91, 37-40.

Di Stefano, R. \& Cravero, M.C., 1992. The separation of hydroxycinnamates in wine. Sci. Alim. 12, 139-144

Di Stefano, R., 1983. Identification of ethyl esters of 2-hydroxyglutaric and 2-hydroxyglutaric- $\gamma$-lactone acids in wines. Vitis, 22, 220-224.

Dubourdieu, D., Tominaga, T., Masneuf, I., Peyrot de Gachons, C. \& Murat, M.L., 2006. The role of yeast in grape flavor development during fermentation: the example of Sauvignon blanc. Am. J. Enol. Vitic. 57, 81-88.

Dubourdieu, D. \& Lavigne, V., 1990. Incidence de 1'hyperoxygénation sur la composition chimique et les qualités organoleptiques des vins blancs secs du bordelais. Rev. Fr. d'Oenologie 124, 58-61.

EEC, 1990. European Communities. Commission Regulation No. 2676/90 on "Community Analysis Methods to Use in Wine Sector". Official J. European Communities L272/3.10.90.

Fernández-Zorbano, P., Ferreira, V., Escudero, A. \& Cacho, J., 1995. Role of hydroxycinnamic acids and flavanols in the oxidation and browning of white wines. J. Agric. Food Chem. 46, 4937-4944.

Fernández-Zorbano, P., Ferreira, V., Peña, C., Escudero, A., Serrano, F. \& Cacho, J., 1998. Prediction of oxidative browning in white wines as a function of their chemical composition. J. Agric. Food Chem. 43, 2813-2817.

Franciolo, S., Torrens, J., Riu-Aumatell, M., López-Tamames, E. \& Buxaderas, S., 2003. Volatile compounds by SPME-GC as age markers of sparkling wines. Am. J. Enol. Vitic. 54(3), 158-162.

Gianotti, S. \& Di Stefano, R., 1991. Metodo per la determinazione dei composti volatili di fermentazione. L'Enotecnico 27(10), 61-64.

Houtman, A.C. \& Du Plessis, C.S., 1986. The effect of grape cultivar and yeast strain on fermentation rate and concentration of volatile components in wine. S. Afr. J. Enol. Vitic., 7(3), 14-20.

Iglesias, J.L.M., Dabiila, E.H., Marino, J.I.M., De Miguel Gordillo, C. \& Exposito, J.M., 1991. Biochemical aspects of the lipids of Vitis vinifera (Macabeo variety). Part 1. Linoleic and linalenic acids as aromatic precursors. Nahrung 35, 705-710.

Macheix, J.J., Sapis, J.C. \& Fleuriet, A., 1991. Phenolic compounds and polyphenoloxidase in relation to browning in grapes and wines. Crit. Rev. Food Sci. Nutr. 30, 441-486.
Makhotkina, O. \& Kilmartin, P., 2009. Uncovering the influence of antioxidants on polyphenol oxidation in wines using an electrochemical method: cyclic voltammetry. J. Electroanal. Chem. 633, 165-174.

Marais, J. \& Pool, H.J., 1980. Effect of storage time and temperature on the volatile composition and quality of dry white table wine. Vitis 19, 151-164.

Murat, M.L., Tominaga, T. \& Dubourdieu, D., 2001. Assessing the aromatic potential of Cabernet Sauvignon and Merlot musts used to produce rose wine by assaying the cysteinylated precursor of 3-mercaptohexan-1-ol. J. Agric. Food Chem. 49(11), 5412-5417.

Nicolini, G., Versini, G., Amadei, E. \& Marchio, M., 1996. 3-hexen-1-ol isomers in Müller-Thurgau wines: "varietal" characteristic affected by must sulfiting time. Vitis 38(3), 147-148.

Okuda, T. \& Yokotsuka, K., 1999. Levels of glutathione and activities of related enzymes during ripening of Koshu and Cabernet Sauvignon grapes and during winemaking. Am. J. Enol. Vitic. 50(3), 264-270.

Peyrot des Gachons, C., Tominaga, T. \& Dubourdieu, D., 2000. Measuring the aromatic potential of Vitis vinifera L. Cv. Sauvignon Blanc grapes by assaying S-cysteine conjugates, precursors of the volatile thiols responsible for their varietal aroma. J. Agric. Food Chem. 48(8), 3387-3391.

Rigaud, J., Cheynier, V., Souquet, J.M. \& Moutounet, M., 1991. Influence of must composition on phenolic oxidation kinetics. J. Sci. Food Agr. 57, 55-63.

Rigaud, J., Cheynier, V., Souquet, J.M. \& Moutounet, M., 2006. Influence of must composition on phenolic oxidation kinetics. 57(1), 55-63.

Rigaud, J., Cheynier, V., Souquet, J.M. \& Moutounet, M., 1990. Mecanismes d'oxydation des polyphenols dans les mouts blancs. Rev. Fr. d'Oenologie 124, 27-31.

Roessler, E.B., Pangborn, R.M., Sidel, J.L. \& Stone, H., 1978. Expanded statistical tables for estimation significance in paired-preference, paired-difference, duo-trio and triangle tests. J. Food Sci. 43, 940-943.

Schneider V., 1998. Must hyperoxidation: a review. Am. J. Enol. Vitic. 49(1), 6573.

Singleton, V.L., 1987. Oxygen with phenols and related reactions in musts, wines, and model systems: observations and practical implications. Am. J. Enol. Vitic. $38,69-77$.

Singleton, V.L., Salgues, M., Zaya, J. \& Trousdale, E., 1985. Caftaric acid disappearance and conversion to products of enzymic oxidation in grape must and wine. Am. J. Enol. Vitic. 36, 50-56.

Spanos, G.A. \& Wrolstad, R.E., 1992. Phenolics of apple, pear, and white grape juices and their changes with processing and storage. A review. J. Agric. Food Chem. 40, 1478-1487.

Tominaga, T., Masneuf, I. \& Dubourdieu, D., 2003. Powerful aromatic volatile thiols in wines made from several Vitis vinifera grape varieties and their releasing mechanism. Nutraceutical Beverages, 24, 314-337.

Tominaga, T., Peyrot de Gachons, C. \& Dubourdieu, D., 1998. A new type of flavor precursors in Vitis vinifera L. cv. Sauvignon blanc: S-cysteine conjugates. J. Agric. Food Chem. 46, 5215-5219.

Tulyathan, V., Boulton, R.B. \& Singleton, V.L., 1989. Oxygen uptake by gallic acid as a model for similar reactions in wine. J. Agric. Food Chem. 37, 844-849.

Usseglio-Tomasset, L. \& Garcia Moruno, E., 1993. Il calcolo del bitartrato di potassio in sovrasaturazione e la valutazione dell'alcalinità delle ceneri. L'Enotecnico 29, 37-41

Usseglio-Tomasset, L., 1995 (4 $4^{\text {th }}$ ed). Chimica Enologica. AEB, Brescia.

Wissemann, K.W. \& Lee, C.Y., 1980. Polyphenoloxidase activity during grape maturation and wine production. Am. J. Enol. Vitic. 31(3), 206-211.

Zamora, R., Maynar, J.I. \& Mesias, J.L., 1985. Lipoxygenase activity in grapes (cv. Macabeo). I. Evidence and partial purification. Am. J. Enol. Vitic. 36, 316318. 